\title{
REKONSTRUKSI METODOLOGI KEILMUAN SYARAH HADIS KLASIK
}

\author{
Yunita Kurniati \\ UIN Raden Fatah, yunitakurniati299@gmail.com
}

\author{
Diterima: 28 Desember $2019 \quad$ Direvisi: 13 Juni $2020 \quad$ Diterbitkan: 30 Juni 2020
}

\begin{abstract}
This paper aims to review the methodology of classical hadith syariah. For this reason, the question of how the classical methodology of hadith is being pursued in this paper. The method used is qualitative with a literature study approach. The results obtained are that the Islamic scientific tradition began at the time of the Prophet (PBUH), in writing, then after entering into the time of friends then the Islamic scientific tradition was held in written form. It is also the beginning of the emergence of the tradition of hadith. Hadith shari'ah in oral form occurred during the time of the Prophet PBUH, while shari'ah hadith in written form occurred during the time of companions. The difference in scientific traditions, since the time of the Prophet, until friends also influence the use of the methodology of the tradition of tradition, even along with the development of the era of science and also the methodology in the tradition of tradition. The method used by hadith scholars in giving tradition is ijmali, which is a method that explains the meaning in general and concise. Even so a review of him in the present is very well done, especially for the development of scientific knowledge related to the tradition.
\end{abstract}

Keywords: Islamic Teaching, Methodology, Tradition.

\begin{abstract}
Abstrak
Tulisan ini bertujuan untuk mengkaji ulang tentang metodologi syarah hadis klasik. Untuk itu pertanyaan tentang bagaimana metodologi syarah hadis klasik adalah yang diupayakan dalam tulisan ini. Metode yang digunakan adalah kualitatif dengan pendekatan studi kepustakaan. Hasil yang didapat adalah bahwa tradisi keilmuan Islam berawal pada masa Nabi saw., secara tertulis, kemudian setelah masuk pada masa sahabat barulah tradisi keilmuan Islam diadakan dalam bentuk tertulis. Hal tersebut juga merupakan awal dari munculnya syarah hadis. Syarah hadis dalam bentuk lisan terjadi pada masa Nabi saw., sedangkan syarah hadis dalam bentuk tertulis terjadi pada masa sahabat. Perbedaan tradisi keilmuan tersebut, sejak pada masa Nabi saw., hingga sahabat berpengaruh juga dalam penggunaan metodologi syarah hadis, bahkan seiring dengan berkembangnya zaman berkembang pulalah ilmu pengetahuan dan juga metodologi dalam syarah hadis. Adapun metode yang digunakan oleh ulama hadis dalam mensyarah hadis adalah ijmali, yakni suatu metode yang menjelaskan makna secara umum dan ringkas. Meskipun begitu pengkajian ulang terhadapnya di masa sekarang sangatlah baik dilakukan, terutama bagi pengembangan keilmuan hadis yang berkaitan dengan syarah hadis.
\end{abstract}

Kata Kunci: Tradisi keilmuan Islam, Metodologi, Syarab Hadis Klasik

\section{PENDAHULUAN}

Permasalahan metodologi sejauh ini masih terus diperbincangkan. Hal ini karena fungsinya dalam ranah ilmu pengetahuan sangatlah penting. Metodologi adalah dasar dari adanya sebuah ilmu pengetahuan. Penggunaan metodologi yang tepat akan melahirkan ilmu pengetahuan yang tepat pula. Selain itu, perkembangan terhadapnya juga akan memberikan pengaruh bagi pengembangan ilmu pengetahuan. Hal serupa juga terjadi dalam metodologi pemahaman hadis, bahkan hingga sampai saat ini juga masih mengalami perbincangan. Mengingat metode syarah hadis itu sendiri adalah alat atau cara untuk memahami hadis. Maka ulama yang ingin mensyarah hadis haruslah paham betul tentang metodologi mana yang harus ia 
gunakan dalam mansyarah hadis, disamping akan membantunya memudahkan dalam mensyarah hadis, penggunaan metode juga penting bagi pembaca dalam memahami syarah hadis. ${ }^{1}$

Ada banyak manfaat yang bisa didapat dari penggunaan metodolgi, karena ia bisa digunakan dalam semua cabang ilmu pengetahuan. Seperti sains, filsafat dan ilmu pengetahuan umum yang lainnya, serta juga agama. Sebagaimana salah satu aliran filsafat yakni rasionalisme yang menyatakan bahwa ilmu pengetahuan itu dapat didapat melalui akal rasional, ${ }^{2}$ kemudian sains melahirkan ilmu pengetahuan melalui eksperimen, begitu pun dengan agama, di mana ilmu pengetahuan itu bisa didapat dengan memadukan antara wahyu dengan akal rasional.

Manfaat yang didapat dalam metodologi juga dirasakan dari tradisi keilmuna Islam, terutama masa klasik. Sebagaimana yang kita ketahui bahwa pada masa klasik, tradisi keilmuan Islam dibedakan menjadi dua, yaitu tradisi lisan dan tertulis. Awal mula tradisi keilmuan Islam itu terjadi pada masa Nabi saw. Di mana pada saat itu, Nabi saw memberikan informasi tentang wahyu yakni alquran melalui lisan. Saat itu, ketika Beliau mendapatkan wahyu, Ia langsung memberikan informasi tersebut kepada para sahabat dalam sebuah majlis atau perkumpulan lain. Hal serupa juga dilakukan oleh Nabi saw., terkait dengan hadis, para sahabat langsung merekam apa yang disampaikan oleh Nabi saw melalui hapalan, adapun tindakan Nabi saw., mereka rekam melalui pengalaman. Dan yang juga patut diketahui bahwa, tradisi keilmuan Islam dalam bentuk lisan ini tidak hanya terjadi

${ }^{1}$ Aan Supian, Metode Syarah Fath Al Bari (Studi Syarah Hadis Pada Bab Halawah Al Iman, Jurnal Nuansa X, NO. 1, 2017, 25.

2 Amsal Bakhtiar, Filsafat Ilmu, Jakarta, Raja Grafindo Persada, 2005, 102. pada masa Nabi saw., saja tetapi terjadi juga pada masa Khulafaur Rasyidin dan juga tabi'in. ${ }^{3}$

Kemudian setelah masa sahabat, kegiatan pengumpulan hadis mulai dilakukan. Karena selain untuk menjaga kelestarian dari hadis itu sendiri dan untuk memisahkan hadis dengan ucapan para sahabat. Pada masa ini juga banyak terdapat golongan ingkar sunah dan para pembuat hadis palsu, maka untuk menjaga hadis agar tidak tercampur dengan ucapan para sahabat dan hadis palsu, pengumpulan hadis dilakukan. Dan seiring dengan dikumpulkannya hadis dalam sebuah kitab, maka tradisi keilmuan Islam dalam bentuk teks juga digalakkan. ${ }^{4}$

Perbedaan tradisi keilmuan Islam baik itu secara lisan maupun tertulis membawa dampak pada pengkajian terhadap syarah hadis klasik. Embrio kemunculan syarah hadis berasal dari Nabi saw., sendiri karena apa yang ada padanya baik itu dari segi ucapan, tindakan adalah hadis. Adapun yang dimaksud syarah hadis pada masa ini adalah penjelasan Nabi saw terkait dengan hadis-hadis yang menjadi pertanyaan dari sahabat. Dan jawaban dari Nabi saw kepada sahabat itulah yang disebut dengan syarah hadis. Adapun kemunculan syarah hadis dalam bentuk teks terjadi ketika munculnya tradisi tulis itu sendiri, yakni muncul pertama kali pada tahun $656 \mathrm{M}$. Pada masa ini, banyak sekali muncul kitab-kitab syarah hadis yang dibuat oleh ulama klasik. Mereka bersama-sama bersemangat untuk menjelaskan hadis-hadis yang telah dihimpun agar maksud yang ingin disampaikan dalam suatu hadis dapat dengan mudah dimengerti. ${ }^{5}$

Adapun metodologi yang digunakan oleh ulama syarah hadis klasik lebih

\footnotetext{
3 Syuhudi Ismail, Metodologi Penelitian Hadis Nabi, Jakarta, Bulan Bintang, 2007, 16.

4 Hani Hilyati Ubaidah, Kajian Syarah Hadis (Studi Teks Kitab Misbah Al Zalam Syarh Bulugh Al Maram Min Adillati Al Ahkam), UIN Syarif Hidayatullah Jakarta, 2019, 23.

5 Alfatih Suryadilaga, Metodologi Syarah Hadis, Yogyakarta:, SUKA Press, 2012, 10.
} 
banyak menggunakan metode ijmali, yang memberikan penjelasan hadis dengan sederhana dan mudah dipahami. Latar belakang penggunaan metode tersebut adalah untuk menghidupkan kembali hadis-hadis yang telah diriwayatkan tersebut dengan harapan agar pengkajian terhadap hadis dapat terus berjalan. Hal tersbeut disebabkan karena banyaknya para periwayat hadis yang membuat kitab kumpulan hadis yang shahih seperti yang ada dalam kutub al Sittah, membuat para ulama hadis setelahnya merasa bahwa hadis tersebut sudah lengkap dan tidak perlu lagi ada periwayatan hadis, sehingga pengkajian terhadap hadis sempat stagnan dan tidak ada pengkajian terhadap hadis demi untuk perkembangan hadis tu sendiri. Untuk itulah mengapa pengkajian terhadap syarah hadis dilakukan.

Syarah hadis bertujuan untuk memberikan penjelasan yang lebih rinci tentang suatu kitab-kitab hadis yang dibuat oleh para perawi hadis. Jika dalam suatu kitab hadis terdapat kumpulan-kumpulan hadis, maka dalam syarah hadis akan dijelaskan juga tentang makna yang terkandung dalam suatu matan. Selain itu, akan dijelaskan juga secara lebih rinci mengenai sanadnya. Sehingga pembaca akan mendapatkan gambaran yang lebih kompleks dari suatu hadis, dan akan lebih mudah memahami tentang apa yang dimaksud oleh suatu hadis, serta jauh dari kekeliruan dalam menangkap makna hadis itu sendiri. ${ }^{6}$ Selain itu, syarah hadis juga berfungsi untuk memberikan gambaran perbedaan mengenai hadis yang bisa dicontoh oleh umat Islam dan hadis yang hanya bisa dilakukan oleh Nabi saw., sebagai seorang nabi dan rasul. $^{7}$

6 Abdul Latif Abdul Razaq, "Kedudukan Syrah Dalam Trdisi Islam," Al Hikmab Vol. 2 (1998): 46.

7 Mukhlis Mukthar, "Syarh Al Hadis Dan Fiqh Al Hadis (Dalam Upaya Memahami Dan Mengamalkan Hadis)," Jurnal Ash Shababah Vol. 4 No. (2018): 117.
Pada abad klasik perkembangan syarah hadis belum begitu pesat, Para pensyarah hadis dalam mensyarah hadis, masih bergantung dengan kitab hadis yang disyarahnya. Mereka tidak begitu banyak dalam melakukan perubahan, hanya saja diberikan uraian secara global dan sederhana terkait dengan hadis yang disyarahnya. Selain itu, kitab yang diangkat tidak jauh dari kitab aslinya. Pendekatan yang digunakan juga tidak begitu banyak. Hal ini tentu sejalan dengan belum berkembangnya ilmu pengetahuan dalam Islam, hingga pendekatan yang dipakai banyak menggunakan pendekatan bahasa dan sejarah, yang tentunya dikaitkan juga dengan keilmuan yang dimiliki oleh pensyarah hadis sesuai dengan latar belakanganya. ${ }^{8}$

Pemahaman hadis setelah Nabi saw., yakni masa sahabat dan tabiin belum banyak menghadapi masalah. Para ulama hadis dalam mensyarah hadis dengan cara menunjukkan makna yang sebenarnya, terkait dengan keilmuan mereka. Mereka juga berkomitmen untuk menjaga hadis agar tetap bisa dijadikan landasan dalam menjalani kehidupan sesuai dengan agama. Itulah mengapa dalam mensyarah hadis, baik itu corak maupun pendekatan yang mereka lakukan tidak lepas dari unsur historis dan bahasa, serta menggunakan metode yang global yang menjelaskan hadis secara sederhana agar mudah dimengerti. ${ }^{9}$

Seiring dengan perkembangan zaman, generasi pun juga berubah, hal tersebut mempengaruhi pensyarahan hadis yang sebelumnya dilakukan sangat hati-hati, serta menggunakan corak, pendektan dan metode yang kira-kira dapat mendukung dalam menjaga makna yang terkandung dalam hadis agar tidak melenceng terlalu jauh. Sebaliknya kini, pensyarahan hadis memiliki banyak

\footnotetext{
8 Ahmad Irfan Fauji, "Pergeseran Metode Pemahaman Hadis Ulama Klasik Hingga Kontemporer," (UIN Syarif Hidayatullah, 2018), 66. 9 Supian, Metode Syarah Fath Al Bari..., 24.
} 
perubahan, baik itu dari segi corak, metode atau pun pendekatan. Selain itu, banyak ulama hadis klasik dalam mensyarah hadis dengan menyuguhkan hadis yang dapat mendukung golongan mereka agar menjadi kuat, bahkan tak sedikit juga dari mereka yang menyuguhkan makna hadis yang jauh dari maksud yang sebenarnya. Hal tersebut sangtlah berbahaya karena dapat membuat orang yang membacanya menjadi tersesat, dan juga dapat membuat citra hadis yang positif menjadi tidak baik. Untuk itu, karya ulama syarah hadis perlu di apresiasi secara positif dan juga dikritisi. ${ }^{10}$

\section{HIPOTESIS}

Tradisi keilmuan Islam membentuk suatu peradaban Islam. Di mana pada setiap masa terjadi perbedaan dan perkembangan, khususnya berkaitan dengan keilmuan Islam. Perbedaan tersebut dapat dilihat salah satunya pada proses pensyarahan hadis, hadis yang sebelumnya dikumpulkan dalam suatu kitab kumpulan hadis, lalu kemudian berkembang, hingga dalam suatu kitab hadis tidak hanya berisi tentang kumpulan hadis saja, tetapi ada juga penjelasan makna yang terkandung di dalamnya yang disebut dengan syarah hadis.

Metodologi yang digunakan oleh ulama tafsir hadis pada masa klasik dalam mensyarah hadis masih bersifat umum dan sederhana, demi untuk mendapatkan penjelasan yang sederhana hingga maksud yang dikandung dalam suatu hadis dapat dengan mudah dimengerti. Latar belakang penggunaan metode yang global ini adalah karena tujuan dari kegiatan syarah hadis itu sendiri yang awalnya agar kegiatan pengkajian hadis yang sempat terhenti dapat terus berjalan.

Metodologi dalam men-syarah hadis saling berkaitan pada setiap masanya, metodologi yang ada pada masa klasik akan mempengaruhi metodologi yang terjadi pada abad pertengahan, metodologi yang digunakan pada abad pertengahan akan berpengaruh juga pada metodologi dalam mensyarah hadis pada abad modern begitu seterusnya. Untuk itu, maka metodologi syarah hadis klasik perlu ditelaah ulang, demi pengembangan keilmuan Islam. Apalagi jika dilihat metodologi yang diterapkan oleh para ulama hadis pada masa kini banyak digunakan oleh para ulama dalam mendukung kelompok mereka agar menjadi kuat, bahkan makna yang diberikan sangat jauh dari makna yang sesungguhnya.

\section{REVIEW ITERATUR}

Untuk membuktikan bahwa tulisan ini merupakan tulisan yang dibuat sebenarbenarnya dari penulis, dan belum pernah ada tulisan yang sebelumnya terkait dengan judul ini, maka berikut akan disebutkan beberapa kajian literatur terdahulu yang berkaitan dengan judul tulisan ini, di antaranya yaitu:

Pertama, Jurnal yang dibuat oleh Mukhlis Mukhtar yang berjudul Syarh al Hadis dan Fiqh al-Hadits. Dalam jurnal tersebut Mukhlis menjelaskan tentang perbedaan antara Syarh al Hadis dan Figh al-Hadits. Dalam jurnal tersebut didapat kesimpulan bahwa hadis adalah sumber hukum kedua setelah alquran, yang bisa dijadikan sebagai sandaran bagi seseorang dalam menajani kehidupannya. Maka, hal yang perlu dipelajari adalah bagaimana agar hadis-hadis yang ada bisa dijadikan pedoman bagi manusia disetiap zaman, bukan hanya bisa dijadikan sebagai landasan bagi zaman di mana hadis itu sendiri dilahirkan. Untuk itu, menurut Mukhlis kita harus mengetahui kapan hadis itu bisa dilihat dari sisi teks saja, dan kapan ia dilihat dari sisi kontekstualnya. Sehingga fungsi dari hadis itu sendiri dapat digunakan. Hal tersebut dapat

10 Ibid., 25. 
dilakukan dengan cara syarh al hadis dan Fiqh al-Hadits. ${ }^{11}$

Meskipun begitu, dalam jurnal tersebut juga memiliki kelemahan yakni hanya dijelaskan mengenai bagaimana kita bisa memahami hadis dari segi syrah al hadis dan Figh al-Hadits saja, serta penerapannya untuk memahami hadis yang bisa dipahami secara tekstual dan kontekstual. Tidak dijelaskan secara rinci mengenai pengertian dari syarh al hadis dan Figh al-Hadits itu sendiri. Seperti sejarah, metodologi yang digunakan, dan pendekatan terkait dengan kedua hal tersebut.

Kedua, Fakhri Tajuddin Mahdi dalam Tesisinya yang berjudul Metodologi Syarah Hadis Nabi saw (Telaah Kitab Tanqih al Qaul Al Hasis Fi Syarb Lubab Al Hadis karya Imam Nawawi Al Bantani). Dalam tesis tersebut, Fakhri menjelaskna terlebih dahulu apa itu syarah hadis, macam-macam metodologi dalam mensyarah hadis, pendekatan syarah hadis, dan juga teknik interpretasi dalam mensyarah hadis. Kemudian di bab selanjutnya baru ia menjelaskan tentang metodologi syarah hadis yang dibuat oleh Nawawi. ${ }^{12}$

Dari tesisnya tersebut di dapat kesimpulan bahwa metodologi yang digunakan oleh Nawawi dalam mensyarah hadis adalah metode ijmali, dengan pendekatan teologis, linguistik dan antropologi. Adapun interpretasi yang ia pakai adalah tekstual dan intertekstual.

Adapun kelemahan yang ada dalam tesis tersebut di atas adalah ia tidak banyak menjelaskan tentang bagaimana Nawawi dalam mensyarah hadis, malah ia lebih banyak menjelaskan tentang pengertian, metodologi, pendekatan dan teknik interpretasi dengan luas, sementara syarah hadis yang dibuat oleh Nawawi tidak banyak diberikan penjelasan.

${ }^{11}$ Mukthar, "Syarh Al Hadis Dan Figh Al Hadis (Dalam Upaya Memahami Dan Mengamalkan Hadis),."

12 Fakhri Tajuddin Mahdy, "Metodologi Syraah Hadis Nabi Saw (Telaah Kitab Tanqih Al Qaul Al Hadis Fi Syarh Lubab Al Hadis Karya Imam NawawiAl Bantani)," (Pascasarjana Univ. Alaudin Makasar, 2018).

\section{METODOLOGI}

Kata metode berasal bahasa Yunani yakni methodos yang berarti jalan sampai. Metode adalah suatu cara yang digunakan dalam melakukan sesuatu secara konsisten agar mendapatan hasil yang diharapkan. Cara tersebut digunakan untuk memberikan kemudahan sehingga dapat menggapai apa yang diharapkan. ${ }^{13}$ Adapun metodologi berarti kaitan antara methodos dan logos, yang artinya ilmu yang membahas tentang metode-metode. Metodologi juga menetukan standar-standar diterimanya suatu kejadian dan menentukan peran berpikir di dalam investigasi. Selain itu, metodologi melibatkan ketetapan metodemetode dan teknik-tekni berpikir yang digunakan dalam suatu investigasi. ${ }^{14}$

Adapun metodologi yang digunakan dalam tulisan ini dalam membantu pengumpulan data serta menggali semua informasi yang menyangkut semua data penelitian ialah kualitatif dengan pendekatan studi kepustakaan. Penelitian ini bersifat kepustakaan murni yang data-datanya diambil dari berbagai buku dan literatur yang berkaitan dengan masalah yang ingin dipecahkan. Adapun sumber yang dijadikan bahan rujukan dalam tulisan ini adalah karya-karya yang berkaitan dengan syarah hadis klasik.

\section{TRADISI KEILMUAN ISLAM DAN METODOLOGI SYARAH HADIS KLASIK}

Istilah syarah berasal dari bahasa Arab yakni syarh yang berarti menerangkan, Yasrahu yang berarti membukakan dan sharhan yang berarti melapangkan. ${ }^{15}$ Sedangkan hadis berarti

${ }^{13}$ Departemen Pendidikan Nasional, Kamus Besar Bahasa Indonesia, Edisi 3, Jakarta, Balai Pustaka, 2001.

14 Syafa'atun Nahruyah, Metodologi Dalam Ekonomi Islam, Jurnal Maro: Ekonomi Syariah Dan Bisnis, Vol. 1, 2018, 14.

15 Departemen Pendidikan Nasional, Kamus Besar Bahasa Indonesia, Jakarta, Gramedia Pustaka Utama, 2008, 1367. 
segala sesuatu yang disandarkan kepada Nabi saw, baik itu perkataan maupun perbuatan. Adapun syarah hadis berarti menjelaskan keshahihan dan kecacatan matan dan sanad hadis, menjelaskan makna-maknya, serta menjelaskan hukum dan hikmahnya. ${ }^{16}$ Pengertian tersebut jika dikaitkan dengan klasik berarti berkaitan dengan periode atau masa, yakni klasik. Syarah hadis klasik berarti syarah hadis yang dilakukan oleh ulama-ulama klasik. Di antaranya adalah Nama' fi sarh al Muwata karya Ahmad Ibn Nasr al Daudi al Sadi (w. 402 H), Syarh Sabih al Bukhari li Ibn al Batal karya Ab Al Hasan Ali Ibn Khalaf Ibn al Al Malik (w. 449 H). ${ }^{17}$

Adapun metode yang digunakan dalam syarah hadis klasik adalah pertama, ijmali. Secara bahasa ijmali berarti ringkas, dan umum. $^{18}$ Secara istilah ijmali berarti menguraikan makna yang terkandung dalam suatu hadis yang disyarah dengan makna yang singkat dan dengan bahasa yang sederhana, namun tepat dalam menarik benang merah dari isi kandungan hadis tersebut. ${ }^{19}$ Di antara kitab yang termasuk dalam kategori ini adalah 'Aun al Ma'bud Syarh Sunan Abi Daud karya Muhammad bin Asyraf bin Ali Haidar al Siddiq Azim Abadi. ${ }^{20}$

Kedua, tablili. Tablili berasal dari bahasa Arab ballala-yuballilu-tablili yang berarti menguraikan dan menganalisis segala sisi dari suatu hadis. Di mana para pensyarah hadis nantinya akan menjelaskan hadis demi hadis, atau kata per kata yang urutannya sesuai dengan kitab yang disyarahnya, dan dari situ

16 Mujiono Nurkholis, Metodologi Syarah Hadis, Bandung, Fasygil Grup, 2003, 3.

17 Sandi Santoso, Melacak Jejak Pensyarahan Kitab Hadis, Jurnal Diroyah: Ilmu Hadis Vol 1, 2016, 82.

18 Faisholudddin Amien, Metode Pemahaman Hadis Antara Kitab Subul Al Salam Dan I'lam Alanam, UIN Sunan Ampel, 2019.

19 Moh Muhtador, Sejarah Perkembangan Metode Dan Pendekatan Syarah Hadis, Jurnal Riwayah: Studi Hadis, Vol 2, 2016, 266.

20 Suryadilaga, Metodologi Syarah Hadis, 13. akan didapat maksud yang dikandung dalam suatu hadis yang disyarah. ${ }^{21}$ Di antara kitab yang masuk dalam kategori ini adalah kitab fath al Bari bi Syarh Sahih al Bukhari karya Ibn Hajar al Asqalani $(77 \mathrm{H}-852 \mathrm{H}){ }^{22}$

Ketiga, Muqarran. Metode ini adalah suatu metode yang digunakan oleh ulama syarah hadis untuk menjelaskan hadis yang disyarahnya dengan membandingkan antara dua kitab syarah yang dibuat oleh ulama hadis, dan tentu hadis yang dibandingkan adalah hadis yang memiliki kemiripan dalam hal redaksi. Salah satu contoh kitab syarah hadis yang menggunakan metode ini yaitu 'Umdah al Qari Syarhas Shahih al Bukhari karya Badru al Aini (725-855). ${ }^{23}$

Adapun motivasi para ulama klasik dalam mensyarah hadis adalah untuk menghidupkan kembali sebuah karya yang kelihatannya sudah mati, di mana aktivitas pengkajian hadis sudah mulai ditinggalkan. Banyak orang yang menerima kitab-kitab ulama yang terdahulu, karena kitab tersebut sudah dirasa cukup untuk menjelaskan hadis. Maka, untuk menghidupkan kembali pengkajian terhadap hadis itulah mengapa pengkajian terhadap hadis dilakukan. Pengkajian syarah hadis juga merupakan pengaruh dari tradisi keilmuan Islam.

Ilmu Islam klasik adalah warisan peradaban Islam. Keilmuan Islam lahir sebagai akibat dari para pemikir muslim yang mau mengkaji keilmuan Islam dengan mengumpulkan ilmu-ilmu pada masa sebelumnya, hingga membentuk satu kesatuan kebudayaan keimuan dalam bentuk teks yang dirangkum dalam 4 disiplin ilmu dan dengan corak yang berbeda, seperti kalam dan ushul figh (bayani), falsafah (burbani), dan tasawuf (irfani). Namun, setelah berakhirya masa Ibnu Rusyd terjadi perbedaan diantara ulama klasik, yakni antara syiah dan sunni mengenai

\footnotetext{
${ }^{21}$ Ibid, 19.

${ }^{22}$ Ibid, 12.

${ }^{23}$ Ibid., 13.
} 
keempat disiplin ilmu tersebut. Di mana sunni tidak menerima filsafat sedangkan syi'ah masih menerima filsafat sebagai disiplin keilmuan. Akan tetapi, meskipun terjadi perbedaan di antara mereka, tetapi kita mesti mengapresiasi apa yang dilakukan oleh ulama klasik bagi kemajuan keilmuan Islam, yakni dengan bersifat inklusif terhadap berbagai budaya dari segala penjuru dunia demi pengembangan keilmuan Islam. Disisi lain apa yang dilakukan oleh ulama sunni memberikan dampak terhdap keilmuan Islam, terutama mempengaruhi cara pandang ulama Islam yang lebih menekankan sisi agama dari pada keilmuan yang lainnya. ${ }^{24}$

Hal serupa juga terjadi pada pengkajian syarah hadis klasik. Di mana para ulama hadis klasik dalam mensyarah hadis lebih menekankan pada pendekatan bahasa dan sejarah (asbabul wurud). Tujuan mereka adalah untuk menjaga keaslian dari hadis itu sediri sehingga kaitan dengan keilmuan lain tidaklah dilakukan pada periode ini. Sehingga dalam mensyarah hadis mereka lebih banyak menguraikan maknanya dengan menjelaskan makna yang terkandung dalam bahasa yang dipakai dalam suatu hadis. Serta juga memaknainya dengan melihat aspek historis atau asbabul wurud ketika hadis itu sendiri muncul. Salah satu contoh pensyarahan hadis klasik terdapat pada kitab tanwir al Hawalik, sebagaimann Alfatih menjelaskan, bahwa dalam kitab tersebut terdapat penjelasan dari para syurih yang lain, di antaranya Ibnu Hajar. Dan tak lupa ia pun mencatumkan pendapatnya tentang suatu hadis yang disyarahnya. ${ }^{25}$

Akan tetapi, saat ini ilmu pengetahuan semakin hari semakin berkembang pesat. Bahkan ilmu-ilmu yang sudah ada dapat

\footnotetext{
24 Ichwansyah Tampubolon, Struktur Pradigmatik Ilmu-Ilmu Keislaman Klasik: Dampaknya Terhadap Pola Pikir, Sikap, Dan Perilaku Keberagamaan, Jurnal MIQOT, Vol. XXXVI, 2013, 274.

25 Suryadilaga, Metodologi Syarah Hadis, 162.
}

melahirkan ilmu baru seperti ilmu kedokteran yang melahirkan ilmu baru yang lebih spesifik seperti bioteknologi, yang juga termasuk di dalamnya adalah teknologi bayi cloning. Kemudian ada juga ilmu antropologi yang merupakan ilmu yang mengkaji tentang manusia dari aspek budaya, tingkah laku, dan keberagamannya secara umum. Kini melahirkan ilmu-ilmu baru yang kebih khusus membahas aspek-aspek tersebut. Salah satunya ada yang membahas dari segi fisik manusia, asal usulnya yang disebut juga dengan ilmu antropologi fisik. ${ }^{26}$ Di sisi lain ada juga aliranaliran yang ada dalam filsafat yang juga melahirkan aliran yang baru salah-satunya adalah humansime yang melahirkan aliran eksistensialisme, dan lain-lain.

Perkembangan ilmu pengetahuan dari masa ke masa akan saling berkaitan antara satu dengan yang lain. Perkem tersebut akan mempengaruhi corak dan pendekatan ulama hadis dalam mensyarah hadis. Ulama hadis yang tadinya hanya menggunakan pendekatan bahasa dan sejarah saja, sekarang dalam mensyarah hadis sudah dikaitkan dengan ilmuilmu yang lain, seperi ekonomi, sosial, dan lainlain. Metode yang mereka gunakan juga telah menggunakan metode tematik. Ahmad sebagaimana dikutip oleh Maulana dalam artikelnya yang berjudul Studi Hadis Tematik menyatakan bahwa metode tematik adalah metode pensyarahan hadis yang dipermasalahkan, baik menyangkut aspek ontologisnya maupun aspek epistemologinya dan aksiologisnya saja atau salah satu dari sub aspeknya. ${ }^{27}$ Itulah mengapa sekarang banyak bermunculan kitab syarah hadis dengan menggunakan metode tematik dan dengan seiring berkembanganya ilmu pengetahuan pendekatan yang digunakan juga sudah

26 Lisma, Belajar Antropologi Dan MacamMacam Jenis Cabang Turunan Antropologi, Kompasiana, n.d.

27 Maulana Ira, Studi Hadis Tematik, Jurnal AlBukhari, Vol 1, 2018, 191. 
menggunakan pendekatan yang multidisipliner. Pendekatan dari berbagai disiplin ilmu tersebut bertujuan untuk membuktikan bahwa hadis itu adalah benar yang merupakan petunjuk bagi manusia, serta juga menghindari kekeliruan dalam mencari solusi atas permasalahan yang ada, tanpa harus memilahnya dari keanekaragaman hadis. ${ }^{28}$

Adapun langkah-langkah yang digunakan dalam mensyarah hadis secara tematik di antaranya adalah sebagai berikut:

1. Menentukan sebuah tema yang akan dibahas

2. Menghimpun hadis-hadis yang terjalin dalam tema yang telah ditentukan

3. Menyusun kerangka pembahasan (out line) dan mengklasifikasikan hadis-hadis yang telah terhimpun sesuai dengan spesifik pembahasannya.

4. Mengumpulkan hadis-hadis semakna yang satu peristiwa (tempat dan waktu terjadinya hadis sama)

5. Menganalisis hadis-hadis tersebut dengan menggunakan berbagai teknik dan pendekatan.

6. Meskipun metode ini tidak mengharuskan uraian tentang pengertian kosa kata, namun kesempurnaannya dapat dicapai jika pensyarah berusaha memahami katakata yang terkandung dalam hadis, sehingga akan lebih baik jika pensyarah menganalisis matan hadis yang mencakup pengertian kosa kata, ungkapan, asbab alwurud dan hal-hal lain yang biasa dilakukan dalam metode tablili.

7. Menarik kesimpulan makna yang utuh dari hasil analisis terhadap hadis-hadis tersebut. $^{29}$

Dengan demikian syarah hadis tematik dapat dilakuakn dengan cara mengumpulkan

28 diunduh pada 29 Desember 2019. www. Jenangmadnoe.blogspot.com, "No Title," n.d.

2929 Desember 2019 Mela Oktavia, Metode Pemahaman Hadis Maudui dan Tahlili, Mela Oktavia Blogspot diunduh pada minggu, "No Title," n.d. hadis-hadis sesuai dengan tema-tema yang terkait. Misalnya jika temanya tentang kesehatan, maka segala bentuk kesehatan akan dibahas, mulai dari kesehatan fisik, mental dan lainnya. Berikut akan diberikan contoh terkait dengan pengaplikasian syarah hadis tentang kesehatan, yakni sebagi berikut:

Dari Abu Hurairah Radhiyallahu 'anhu ada seorang laki-laki berkata kepada Nabi saw: "Berilah aku wasiat. Beliau menjawab, "Engkan jangan marah! Orang itu mengulangi permintaannya berulang-ulang, kemudian Nabi saw bersabda: "Engkau jangan marah (HR. Bukhari). ${ }^{30}$

Sahabat yang meminta wasiat dalam hadis ini bernama Jariyah bin Qudamah ra. Ia meminta sahabat dengan Nabi saw dengan sebuah wasiat yang singkat dan padat yang mengumpulkan berbagai perkara kebaikan, agar ia dapat menghapalnya dan mengamalkannya. Maka Nabi saw berwasiat kepadanya agar tidak marah. Kemudian ia memintai permintaannya itu berulang-ulang, sedang Nabi saw tetap memberikan jawaban yang sama. Ini menunjukkan bahwa marah adalah pokkok dari berbagai kejahatan, dan menahan diri dari adalah pokok segala kebaikan.

Marah adalah bara yang dilemparkan setan ke dalam hati anak Adam sehingga ia mudah emosi, dadanya membara, urat sarafnya menegang, wajahnya memerah dan terkadang ungkapan dan tindakannya tidak masuk akal.

Dari Abu Huraira ra dia berkata: Orang-orang miskin dari para sahabat Rasulullah saw, pernah datang menemui beliau, lalu berkata " Wabai Rasulullah saw., orang-orang kaya yang memiliki harta yang melimpah bisa mendapatkan kedudukan yang tinggi disisi Allah SWT., dan kenikmatan yang abadi di surga, karena mereka melaksanakan sholat seperti kami melaksanakan sholat, dan mereka juga berpuasa seperti kami berpuasa, tapi mereka memiliki kelebihan barta yang

${ }^{30}$ Muhammad Ibn Ismail Al Bukhari, Shabih Al Bukhari, Beirut, Dar Ibn Katsir, 2002, 78. 
mereka gunakan untuk menunaikan ibadab baji, umrah, jihad dan sedekah sedangkan kami tidak memiliki harta.(HR. Bukhari). ${ }^{31}$

Dalam HR. Imam Muslim dalam hadis di atas Rasulullah saw bersabda: "Itu adalab karunia dari Allab SWT., yang diberikan-Nya kepada siapa yang dikehendaki-Nya. ${ }^{32}$

Kesimpulannya manusia akan sehat secara naluri jika dalam keadaan baik terpenuhinya naluri beragama dan mempertahankan eksisitensi diri. Naluri beragama adalah berdoa dan beribadah kepada Tuhan, sholat malam, ibadah haji dan umrah. Adapun naluri mempertahankan eksisitensi diri adalah bekerja mencari nafkah, menuntut ilmu untuk memeperluas pengetahuan, menambah keterampilan, jangan marah ketika dihina, jangan sedih ketika dicaci, senang dan gembira manakala dipuji dan dipuja, membela diri atau melawan ketika kehendak dicederai, menjadi kaya (dengan cara yang halal) dan bersedekah. ${ }^{33}$

Tradisi keilmuan dalam Islam mewakili Islam dalam pengembangan peradabannya. Tradisi keilmuman Islam bahkan membawa Islam pada puncak keemasannya. Tradisi keilmuan tersebut menyejarah bahkan sampai sekarang, dan akan terus mengalami perkembangan jika para pemikir Islam mau melanjutkannya. Adapun sumber dari kelilmuan Islam adalah wahyu. Keilmuan Islam berawal dari kebenaran, bukan berdasarkan pada spekulasi yang kemudian membutuhkan pembenaran, tetapi membutuhkan bukti yang memberikan gambaran atau kejelasan bahwa apa yang ada dalam wahyu tersebut adalah benar.

Awal mula tradisi keilmuan Islam berbentuk lisan. Karena pada masa Nabi saw

\footnotetext{
31 Ibid., 206.

${ }^{32}$ Muslim Ibn Al Hajjaj, Shabih Muslim, Riyadh, Dar Thayyibah, 2006, 268.

33 Fadliyanur, Tafsir Dan Hadis Tematik Tentang Kesehatan, Jurnal Al Falah, Vol. XVIII, 2018, 186.
}

dan sahabat, hapalan mereka sangatlah kuat, jadi ketika Rasulullah saw menyampaikan wahyu yang telah diberikan oleh Allah SWT., kepada sahabat, mereka langsung menghapalnya. Di antara sahabat yang banyak dalam hapalannya terutama menghapal alquran adalah Abu Musa Al Asy'ary, sedangkan salah satu ulama yang banyak menghapal hadis adalah Imam Bukhari.

Akan tetapi, meskipun tradisi lisan sangat kuat pada masa Nabi saw dan sahabat bukan berarti bahwa tradisi tulis tidak digalakkan dalam Islam. Tradisi tulis dalam Islam ada setelah adanya pengumpulan alquran dan hadis dalam suatu kitab. Kegiatan pengkajian hadis secara tulis pada masa klasik masih besifat sederhana. Hal ini sangatlah wajar mengingat pada masa ini adalah awal mula lahirnya syarah hadis secara tertulis. Para pensyarah hadis hanya menjelaskan makna yang ada dalam hadis secara global dan dengan bahasa yang sederhana, bahkan terkadang pembaca susah dalam membedakan mana yang termasuk dalam bagian hadis dan mana yang termasuk bagian syarah hadis, disamping itu juga karena kegiatan syarah hadis pada masa ini ditujukkan untuk merokonstruksi kitabkitab hadis yang sudah ada agar pengkajian terhadapnya tetap berjalan.

Untuk bisa melakukan pensyarahan terhadap hadis, para ulama hadis menggunakan suau metode. Metode tersebutlah yang menjadi penuntun bagi mereka dalam menafsirkan hadis, sehingga hadis yang mereka syarah memiliki kesamaan dalam hal penjelasan makna. Adanya keseragaman tersebut membuat pembaca menjadi lebih mudah dalam memahami kitab syarah hadis tersebut. Dengan demikian, usaha dari para ulama klasik dalam mensyarah hadis perlu diapresiasi, karena apa yang mereka lakukan akan memberikan fondasi dasar bagi pengembangan keilmuan terutama terkait dengan syarah hadis. 


\section{KESIMPULAN}

Tradisi keilmuan Islam merupakan bentuk dari pada peradaban Islam. Tradisi keilmuan Islam saling terkait di setiap zaman mulai dari klasik hingga kontemporer. Tradisi keilmuan tersebut mempengaruhi pengkajian syarah hadis klasik, terutama berkenaan dengan metodologinya. Dari zaman klasik hingga kontemporer metodologi yang digunakan ulama syarah hadis klasik mengalami perkembangan. Pendekatan yang mereka gunakan pun juga berkembang, yang semula hanya pendekatan sejarah dan bahasa saja sekarang sudah dikaitkan dengan pendekatan yang multidisipliner.

Meskipun mengalami perkembangan metodologi yang digunakan pada masa sekarang banyak mengalami kelemahan. Hal ini disebabkan karena banyak para ulama yang menggunakan metode syarah hadis yang berkembang saat ini demi untuk menguatkan kelompok mereka, bukan berdasarkan pada apa yang sebenarnya terkandung dalam suatu hadis, bahkan makna yang dimunculkan sudah sangat jauh berbeda dengan makna yang sebenarnya ada. Berbeda dengan metodologi syarah hadis klasik yang masih sangat memperhatikan objektivitas dari makna yang terkandung dalam suatu hadis. Untuk itu maka, pengkajian terhadap metodologi syarah hadis masa klasik perlu dipertimbangkan sebagai bahan rujukan bagi pengembangan hadis di masa sekarang. 


\section{DAFTAR KEPUSTAKAAN}

Amien, Faisholudddin. “, Metode Pemahaman Hadis Antara Kitab Subul Al Salam Dan I'lam Alanam.” UIN Sunan Ampel, 2019.

Bakhtiar, Amsal. Filsafat Ilmu. Jakarta: Raja Grafindo Persada, 2005.

Bukhari, Muhammad Ibn Ismail Al. Shabih Al Bukhari. Beirut: Dar Ibn Katsir, 20002.

Fadliyanur. "Tafsir Dan Hadis Tematik Tentang Kesehatan,.” Jurnal Al Falah, Vol. XVIII, 2018

Fauji, Ahmad Irfan. "Pergeseran Metode Pemahaman Hadis Ulama Klasik Hingga Kontemporer,." UIN Syarif Hidayatullah, 2018.

Hajjaj, Muslim Ibn Al. Shabih Muslim. Riyadh: Dar Thayyibah, 2006.

Ira, Maulana. "Studi Hadis Tematik." Jurnal AlBukbari Vol 1, 2018

Ismail, Syuhudi. , Metodologi Penelitian Hadis Nabi, Jakarta: Bulan Bintang, 2007.

Lisma. "Belajar Antropologi Dan Macam-Macam Jenis Cabang Turunan Antropologi,." Kompasiana, n.d.

Mahdy, Fakhri Tajuddin. "Metodologi Syraah Hadis Nabi Saw (Telaah Kitab Tanqih Al Qaul Al Hadis Fi Syarh Lubab Al Hadis Karya Imam NawawiAl Bantani),." Pascasarjana Univ. Alaudin Makasar, 2018.

Mela Oktavia, Metode Pemahaman Hadis Maudui dan Tahlili, Mela Oktavia Blogspot diunduh pada minggu, 29 Desember 2019. "No Title," n.d.

Muhtador, Moh. "Sejarah Perkembangan Metode Dan Pendekatan Syarah Hadis,." Jurnal Riwayab: Studi Hadis, Vol 2, 2016

Mukthar, Mukhlis. "Syarh Al Hadis Dan Fiqh Al Hadis (Dalam Upaya Memahami Dan Mengamalkan Hadis),." Jurnal Ash Shahabab Vol. 4, 2018

Nahruyah, Syafa'atun. "Metodologi Dalam Ekonomi Islam,." Jurnal Maro: Ekonomi Syariah Dan Bisnis, Vol. 1, 2018

Nasional, Departemen Pendidikan. Kamus Besar Bahasa Indonesia,. Jakarta: Gramedia Pustaka Utama, 2008.

—. Kamus Besar Bahasa Indonesia. Edisi 3. Jakarta: Balai Pustaka, 2001.

Nurkholis, Mujiono. Metodologi Syarah Hadis,. Bandung: Fasygil Grup, 2003.

Razaq, Abdul Latif Abdul. "Kedudukan Syrah Dalam Trdisi Islam,." Al Hikmah Vol. 2 , 1998

Santoso, Sandi. "Melacak Jejak Pensyarahan Kitab Hadis,." , Jurnal Diroyab: Ilmu Hadis Vol 1, 2016.

Supian, Aan. "Metode Syarah Fath Al Bari (Studi Syarah Hadis Pada Bab Halawah Al Iman." Nuansa X, No. 1, 2017

Suryadilaga, Alfatih. Metodologi Syarah Hadis,. Yogyakarta: SUKA Press, 2012.

Tampubolon, Ichwansyah. "Struktur Pradigmatik Ilmu-Ilmu Keislaman Klasik: Dampaknya Terhadap Pola Pikir, Sikap, Dan Perilaku Keberagamaan,." Jurnal MIQOT, Vol. XXXVI, 2013.

Ubaidah, Hani Hilyati. "Kajian Syarah Hadis (Studi Teks Kitab Misbah Al Zalam Syarh Bulugh Al Maram Min Adillati Al Ahkam),.” UIN Syarif Hidayatullah Jakarta, 2019.

www. Jenangmadnoe.blogspot.com, diunduh pada 29 Desember 2019. "No Title,” n.d. 